\title{
Procalcitonin - An Indicator of Sepsis
}

\author{
W. Karzai, A. Meier-Hellmann, and K. Reinhart
}

\section{Introduction}

Sepsis is defined as a systemic inflammatory response to severe infections. However a similar systemic inflammatory response may also be triggered by other insults such as pancreatitis [1], major trauma [2], and burns [3]. Common clinical signs of systemic inflammation such as changes in body temperature, leukocytosis, and tachycardia may therefore have an infectious or non-infectious etiology and are neither specific nor sensitive for sepsis. It is, thus, frequently difficult to distinguish patients with systemic infection from those who appear septic but have no evidence of infection. Bacteriologic evidence of infection also has drawbacks because it may not develop concurrently with clinical signs of sepsis, and a negative bacteriologic result does not exclude the presence of infection or of sepsis [4]. Since these common clinical and laboratory parameters lack sensitivity and specificity, others are needed to provide an early marker of the infectious etiology of a generalized inflammatory response and thus allow early diagnosis and the application of more specific therapeutic interventions. Furthermore, new parameters may also help identify subgroups of septic patients who may benefit from pro- or anti-inflammatory therapies. One such parameter, procalcitonin (PCT), has recently drawn attention as a possible marker of the systemic inflammatory response to infection.

\section{Biology of Procalcitonin}

PCT is the propeptide of calcitonin which consists of 116 amino acids with a molecular weight of $13 \mathrm{kD}[5,6]$, and under normal circumstances, is produced in the C-cells of the thyroid glands. A specific protease then cleaves PCT to calcitonin, katacalcin, and a N-terminal residue [5]. In contrast to the short half-life of calcitonin (10 minutes) PCT has a long half-life of 25-30 hours [7] in serum. PCT levels are undetectable $(<0.1 \mathrm{ng} / \mathrm{ml})$ in healthy humans but increase to over $100 \mathrm{ng} / \mathrm{ml}$ during severe infections (bacterial, parasitic and fungal) with systemic manifestations.

During severe systemic infections, PCT is mostly produced by extra-thyroid tissues. Thus, patients who have previously undergone a total thyroidectomy can still produce high levels of PCT (without secretion of calcitonin) during a severe infectious episode [8]. The exact site of PCT production during sepsis is, however, uncertain. One investigator, using katacalcin antibodies, has identified PCT-like J.-L. Vincent (ed.), Yearbook of Intensive Care and Emergency Medicine 
activity in human leukocytes [9], while others suggest neuroendocrine cells and the lungs [10-12] as possible sites of production. Remarkably, the large amounts of PCT produced during infections do not lead to an increase in plasma calcitonin levels or activity [8] and calcium levels seems to be independent of PCT-like activity.

Procalcitonin is measured with an immunoluminometric assay (B.R.A.H.M.S. Diagnostika, Berlin). This assay is specific in that it uses two antibodies that bind to two sites (calcitonin and katacalcin) of the PCT molecule thus ruling out crossreactivity. The detection limit of the assay is $0.1 \mathrm{ng} / \mathrm{ml}$ and PCT levels of healthy subjects are usually $<0.1 \mathrm{ng} / \mathrm{ml}$ [13]. Previously, some investigators had found increases in serum "calcitonin-like" activity in patients with infections [14] or with lung disease $[10,11]$. However, those methods did not discriminate between calcitonin and PCT although some of the "calcitonin-like" activity in these studies may well have been attributable to increases in PCT levels.

\section{Procalcitonin During Infections}

Severe generalized bacterial, parasitic or fungal infections with systemic manifestations are associated with increased PCT serum levels. In contrast, severe viral infections or inflammatory reactions of non-infectious origin do not, or only moderately increase PCT levels. In a well-documented study [8], 79 children with suspected infections displayed PCT levels which were either very low $(<0.1 \mathrm{ng} / \mathrm{ml})$ in those with no infection, or very high $(6-53 \mathrm{ng} / \mathrm{m})$ in those with severe infection. Antibiotic therapy in those with severe infection led to a resolution of the infection and to decreases in PCT levels. Localized bacterial infections without systemic manifestations, and viral infections, produced only small to modest increases in PCT (0.3-1.5 $\mathrm{ng} / \mathrm{ml}$ ). Calcitonin was undetectable in these patients regardless of how high PCT levels were. Because of these properties, PCT has been proposed as an indicator of severe generalized infections or sepsis $[8,13]$.

\section{Specificity and Sensitivity of PCT}

The specificity of PCT for infections increases with increasing PCT values i.e., patients with PCT values above $1.5 \mathrm{ng} / \mathrm{ml}$ are more likely to have a severe infection (sensitivity $100 \%$, specificity $72 \%$ ) than patients with PCT values above $0.1 \mathrm{ng} / \mathrm{ml}$ (sensitivity $100 \%$, specificity $35 \%$ ) [15]. However, since the number of patients in such studies are limited, both high and low cut-off values of PCT have been used to predict infectious complications in patients with an underlying active inflammatory disease. In patients with pancreatitis, PCT levels greater than $1.8 \mathrm{ng} / \mathrm{ml}$ predicted infectious complications with a diagnostic accuracy of $87 \%$ which was comparable to that of fine-needle aspiration (84\%) [16]. The diagnostic accuracy improved if increases in PCT levels $(>1.8 \mathrm{ng} / \mathrm{ml})$ occurred at least twice during the observation period. In contrast, the cut-off value which was used to predict bacterial infection in patients with underlying active lupus erythematosis was merely $0.5 \mathrm{ng} / \mathrm{ml}$ (unpublished observations) with a sensitivity of 1.00 and a specificity of 0.84 . These fin- 
dings suggest that levels of PCT which best differentiate between infectious and non-infectious states in patients with underlying inflammatory syndrome may depend on the characteristics of the patient population studied.

\section{PCT and Infectious Versus Non-Infectious Causes of Severe Systemic Inflammation}

PCT has been used to differentiate between infectious and non-infectious causes of severe inflammatory states. Preliminary results suggest that PCT helps differentiate infectious (cholangitis by bile duct obstruction) from non-infectious (ethanol) pancreatitis [17], infectious from non-infectious causes of the acute respiratory distress syndrome (ARDS) in adults, and systemic fungal [18] and bacterial infections from episodes of graft rejection [19] in patients after organ transplantation. Although small patient populations and inadequate use of statistics makes it difficult to interpret the results of these studies, they do suggest that PCT levels may help identify non-viral infection as a cause of the systemic inflammatory response.

\section{PCT and Severity of Infection}

PCT levels increase with increasing severity of the inflammatory response to infection. A recent study [15] compared PCT values in patients with bacterial pneumonia and septic shock. PCT values were moderately increased in patients with bacterial pneumonia (mean: $2.4 \mathrm{ng} / \mathrm{ml}$ ) but were markedly increased in patients with septic shock (means: $72-135 \mathrm{ng} / \mathrm{ml}$ ) (Fig. 1). Preliminary results of other studies [20-22] suggest that once the PCT level is increased, it may then reflect the severity of the inflammatory/infectious response. When patients were categorized into systemic inflammatory response syndrome (SIRS), sepsis, severe sepsis, and septic shock using the ACCP/SCCM consensus conference criteria [23]. PCT levels were especially elevated in patients with severe sepsis and septic shock (Table 1).

On the other hand, PCT levels are not, or are only moderately, increased in the systemic inflammatory response to viral or to non-infectious stimuli (infections other than viral). In neonates and children, those with bacterial meningitis had sig-

Table 1. Procalcitonin, TNF- $\alpha$, and IL- 6 values in various stages of the inflammatory/infectious response.

\begin{tabular}{lclc}
\hline & TNF- $\alpha(\mathrm{pg} / \mathrm{ml})$ & IL-6 $(\mathrm{pg} / \mathrm{ml})$ & PCT $(\mathrm{ng} / \mathrm{ml})$ \\
\hline SIRS & $24 \pm 4$ & $269 \pm 22$ & $1.3 \pm 0.2$ \\
Sepsis & $51 \pm 9^{*}$ & $435 \pm 52^{*}$ & $2.0 \pm 0.0^{*}$ \\
Severe sepsis & $59 \pm 17$ & $969 \pm 168^{*}$ & $8.7 \pm 2.5^{\star}$ \\
Septic shock & $118 \pm 18$ & $996 \pm 57$ & $38.6 \pm 5.9^{*}$ \\
\hline
\end{tabular}

Values are expressed as mean \pm SEM. TNF- $\alpha=$ tumor necrosis factor-alpha; IL- 6 = interleukin- 6 ; $\mathrm{PCT}=$ procalcitonin; SIRS $=$ systemic inflammatory response syndrome ${ }^{\star} \mathrm{p}<0.05$ as compared to preceding value. (From [21] with permission) 

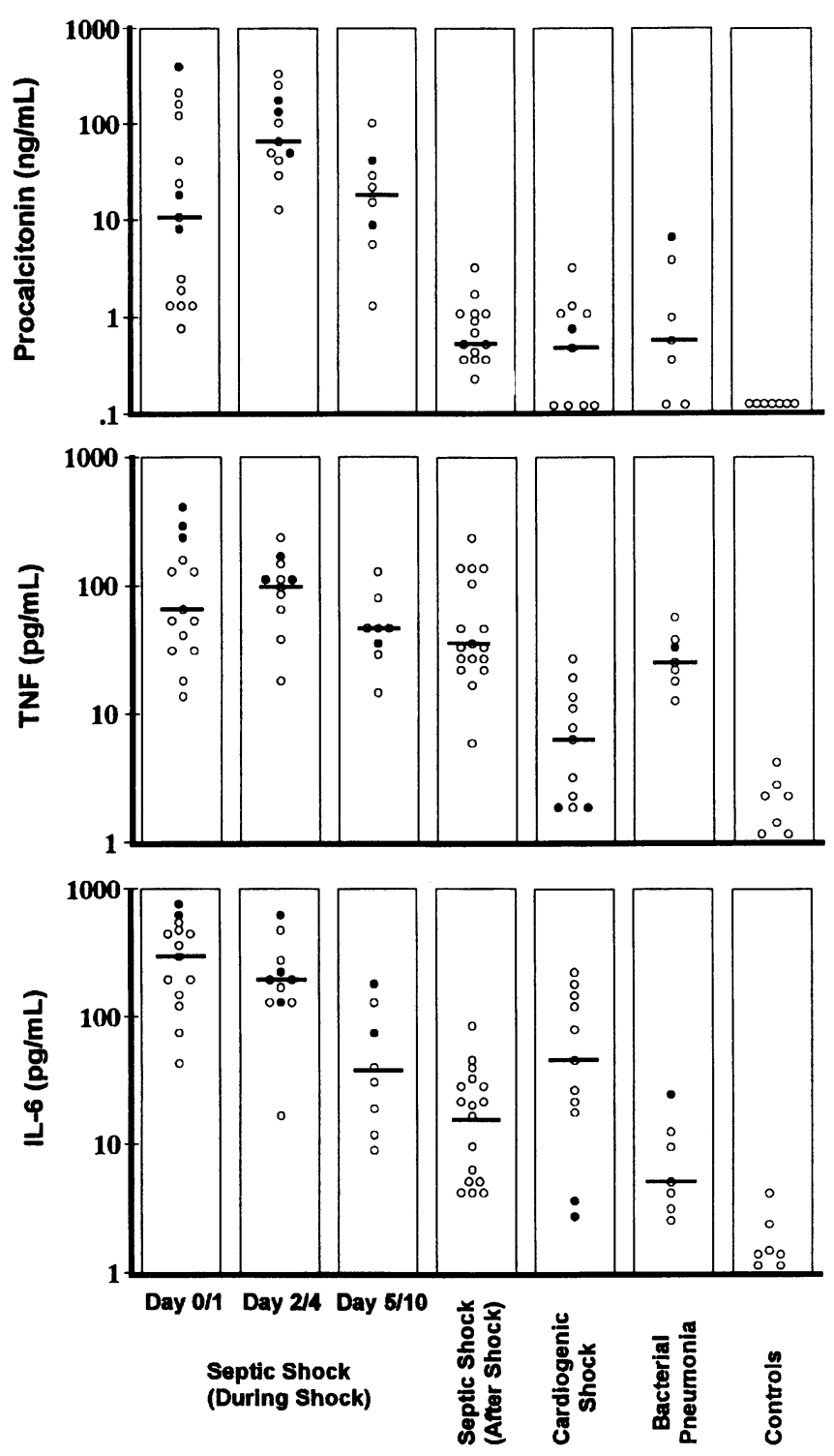

Fig. 1. Concentrations of tumor necrosis factor (TNF)- $\alpha$, interleukin-6 (IL-6), and procalcitonin in the plasma of patients with septic shock, cardiogenic shock, bacterial pneumonia, and in normal volunteers. Open circles: survivors, closed circles: non-survivors. (Modified from [15] with permission)

nificantly higher levels of PCT (mean: $57.9 \mathrm{ng} / \mathrm{ml}$ ) than those with viral meningitis (mean: $0.3 \mathrm{ng} / \mathrm{ml}$ ) (unpublished data). In patients infected with human immunodeficiency virus (HIV), PCT levels were increased only in those with bacterial sepsis, whereas HIV-infection alone, even in the late stages of disease, did not lead to increases in PCT levels [24]. 


\section{PCT and Severity of Disease}

PCT values in cardiogenic shock are only moderately increased (mean $1.4 \mathrm{ng} / \mathrm{ml}$ ) in comparison to the large increases in patients with septic shock (means: 72-135 $\mathrm{ng} / \mathrm{ml}$ ) [15] (Fig. 1). This finding shows that increases in PCT during septic shock are due to the inflammatory reaction to infection and not due to poor organ perfusion. Thus, although the severity of the systemic response to infection is reflected in corresponding increases in PCT levels, even severe disease of non-infectious etiology does not necessarily lead to corresponding increases in PCT levels.

\section{Prognostic Value of PCT}

Since PCT levels increase with increasing severity of the inflammatory response to infection they may be of prognostic value and may help to judge therapeutic efficacy. In patients with melioidosis, infection with Pseudomonas pseudomallei, a fatal outcome was associated with significantly higher levels of PCT than that seen in patients who survived [25]. In a study performed at our institution [26], PCT values obtained on the day sepsis was diagnosed were significantly higher in nonsurvivors of sepsis than in survivors. Furthermore, PCT levels increased during the course of disease in non-survivors whereas they decreased in surviving patients. In pediatric patients, PCT levels fell after successful antibiotic treatment [8]. Therefore, therapies effective in controlling infections and reducing severity of disease may lead to reductions in PCT levels.

\section{PCT and C-reactive Protein}

C-reactive protein (CRP) is also a useful clinical tool in assessing the severity of the inflammatory response to infections. CRP has been successfully used to differentiate between true pneumonia and endotracheal infections in patients with chronic obstructive lung disease [27], to increase diagnostic accuracy in patients with appendicitis [28], to detect post-operative sepsis in infants [29], as an indicator of the resolution of sepsis, and to differentiate between bacterial and viral infections [30]. In a recent study [31], CRP and PCT were simultaneously measured in children with infectious disease. PCT increased earlier and returned to the normal range more quickly than CRP. Our clinical experience suggests that CRP may be an important marker in infections without systemic manifestations where PCT concentrations are usually low. PCT, however, may be a superior marker during infections with systemic manifestations. More studies are needed to determine whether PCT is superior to CRP in differentiating between inflammation of infectious and noninfectious origin. 


\section{PCT and Cytokines}

Cytokines have been implicated in the pathogenesis of severe infections and sepsis. Like PCT, cytokines such as tumor necrosis factor (TNF), interleukin-1 (IL-1) and IL-6 are frequently elevated in patients with severe bacterial infections (sepsis) $[32,33]$. Healthy volunteers injected with Escherichia coli endotoxin developed symptoms of systemic manifestation such as fever, myalgia, and chills 1-3 hours later [34]. PCT levels, undetectable at baseline, started to rise 4 hours after endotoxin and plateaued at $4 \mathrm{ng} / \mathrm{ml}$ at 8-24 hours. TNF and IL-6 levels peaked 2-3 hours after endotoxin and were undetectable at 24 hours (Fig. 2). That the same kinetics can be expected to occur in human septic shock has been recently described in a rare and interesting case [35]. A hemodialysate of calf blood contaminated with Acinetobacter baumanii was injected in a 76 year old patient leading, within hours, to septic shock. TNF was detectable in serum at 1.5 hours, peaked at 3 hours, and declined thereafter. PCT was first detectable at 3 hours, peaked 14 hours after the injection ( $300 \mathrm{ng} / \mathrm{ml}$ ), and remained increased for more than 24 hours. Thus, in response to endotoxin or to live bacteria, increases in circulating PCT levels occur shortly after cytokines have peaked. Differences in the half-lives of PCT (25-30 hours) and the cytokines measured may explain why PCT is detectable longer, or cytokines released after endotoxin administration might induce PCT production. Unpublished observations show that in cancer patients,TNF or IL-2 infusions lead to increases in PCT levels. These reports, if substantiated, could better explain the described kinetics of PCT and cytokines.

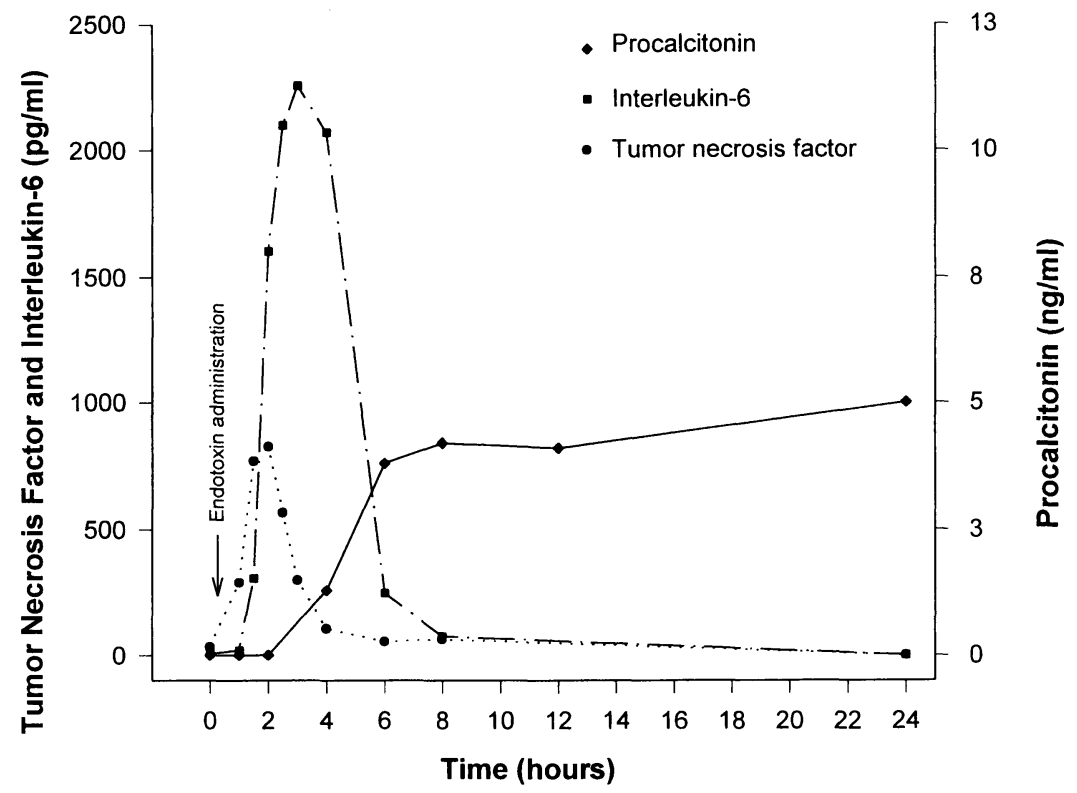

Fig. 2. Serial procalcitonin (PCT), tumor necrosis factor (TNF- $\alpha$ ), and interleukin-6 (IL-6) values after endotoxin administration in humans. (From [34] with permission) 
The chances of detecting elevated cytokine levels during severe infections are limited by their short half-lives. In contrast, PCT remains detectable in blood much longer and correlates more readily with the clinical presentation of the patient. In a study at our institution [20], when compared to TNF and IL-6, PCT best discriminated the severity of the inflammatory infectious response (Table 1). Further, both TNF and IL-6 may decline despite persistence or even increased severity of sepsis, but PCT levels remain elevated or may increase. The same cytokines are also frequently elevated in patients with (inflammatory) autoimmune disease (rheumatoid arthritis, lupus erythematosis), in which PCT remains undetectable [7]. Increases in cytokine levels are not confined to the intravascular space and during infections, cytokine levels in body compartments (pleural fluid, bronchoalveolar fluid, cerebro-spinal fluid, ascites) often exceed cytokine levels in the intravascular space. In contrast, increased PCT levels are mostly confined to the intravascular space and PCT is either undetectable or markedly low in other body compartments [36].

\section{Open Questions Regarding the Biology and Use of PCT}

\section{Biology of PCT}

Despite numerous observational studies, it is still not clear which cells produce PCT during infectious episodes, which stimuli prompt these cells to produce PCT, and what purpose high PCT levels serve during severe infections.

\section{Clinical use of PCT}

Although many clinical studies have been published on PCT, the questions as to whether PCT is a marker of (bacterial, fungal, or parasitic) infection or of the inflammatory response (to infectious or non-infectious stimuli) are not satisfactorily answered. Clearly, PCT is not a marker of infection as such, since localized infections or infections with no systemic manifestation may not cause any appreciable increase in PCT levels [37]. For example, with some exceptions, PCT levels only increase a modest $1-2.4 \mathrm{ng} / \mathrm{ml}$ during community acquired pneumonia [15, 37]. In patients with localized infections without signs of systemic manifestation, therapeutic measures such as antibiotics or surgical intervention may be necessary despite normal PCT levels. Although elevated PCT values during severe infections may decrease to very low levels with appropriate therapy, this does not always indicate complete eradication of the infection but merely that generalization of the infection or the septic response is under control. Continuation of antibiotic therapy or surgical measures may be necessary until all clinical signs of infection have disappeared.

PCT levels may also be elevated during non-infectious inflammatory states. Patients after major trauma or surgery [38,39], and patients after cardiopulmonary bypass [40] may present with increased PCT levels without any evidence of severe infections. In high-risk cardiac surgery patients, PCT was not helpful in differentiating between the inflammatory reaction to infection or to surgery as such [41]. In 
addition, patients with C-cell carcinoma of the thyroid gland [42] and small-cell carcinoma of the lung [43] without underlying infection may also have increased PCT levels.

\section{Conclusion}

PCT may prove to be a valuable indicator capable of identifying the presence and intensity of severe systemic non-viral infections. PCT monitoring may be useful in patients likely to develop a systemic inflammatory response of infectious origin, such as intensive care unit (ICU) patients after major surgery or trauma, ICU patients with nosocomial infections which may lead to sepsis, and immunocompromised patients. Abrupt increases in, or high PCT values in these patients justify a search for a source of infection. PCT measurements may also be helpful in differentiating between infectious or non-infectious causes in patients presenting with SIRS. PCT monitoring may, therefore, be used during pancreatitis (differentiating infectious-cholestatic versus alcohol-toxic), ARDS (differentiating infectious versus noninfectious), and after transplantation (differentiating rejection reaction versus infections). Further, PCT measurements may differentiate between viral and bacterial infections (with systemic manifestation).

\section{References}

1. Steinberg W, Tenner S (1994) Acute pancreatitis. N Engl J Med 330:1198-1205

2. Moore FA, Haenel JB, Moore EE, Whitehill TA (1992) Incommensurate oxygen consumption in response to maximal oxygen availability predicts postinjury multiple organ failure. J Trauma $33: 58-67$

3. Saffle JR, Sullivan JJ, Tuohig GM, Larson CM (1993) Multiple organ failure in patients with thermal injury. Crit Care Med 21:1673-1683

4. Gramm H-J, Reinhart K, Goecke J, Bülow JV (1989) Early clinical, laboratory, and hemodynamic indicators of sepsis and septic shock. In: Reinhart K, Eyrich K (eds) Sepsis - an interdisciplinary challenge. Springer-Verlag, Berlin, Heidelberg, New York, pp 45-57

5. Le Moullec JM, Jullienne A, Chenais J, et al (1984) The complete sequence of preprocalcitonin. FEBS 167:93-97

6. Jacobs JW, Lund PK, Potts JT, Bell HH, Habener JF (1981) Procalcitonin is a glycoprotein. J Biol Chem 256:2803-2807

7. Meissner M (1996) PCT-Procalcitonin. A new and innovative parameter in diagnosis of infections. B.R.A.H.M.S. Diagnostica, Berlin, pp 14-60

8. Assicot M, Gendrel D, Carsin H, Raymond J, Guilbaud J, Bohuon C (1993) High serum procalcitonin concentrations in patients with sepsis and infection. Lancet $341: 515-518$

9. Oberhoffer M, Vogelsang H, Meier-Hellmann A, Jäger L, Reinhart K (1997) Anti-katacalcin-antibody reaction in different types of human leukocytes indicates procalcitonin content. Shock 7 (suppl 1): A487 (Abst)

10. Nylen ES, Snider RH, Thompson KA, Rohatgi P, Becker KL (1996) Pneumonitis-associated hypercalcitoninemia. Am J Med Sci 312:12-18

11. Becker KL, O’Neill W, Snider RH, et al (1993) Hypercalcitoninemia in inhalation burn injury: A response of the pulmonary neuroendocrine cell? Anatomic Record 236:136-138

12. Cate CC, Pettingill OS, Sorensen GD (1986) Biosynthesis of procalcitonin in small cell carcinoma of the lung. Cancer Res 46:812-818

13. Gendrel D, Bohuon CJ (1997) Procalcitonin, a marker of bacterial infection. Infection 133-134 
14. Mallet E, Lanse X, Devaux AM, Ensel P, Basuyau JP, Brunelle P (1983) Hypercalcitoninemia in fulminant meningococcaemia in children. Lancet 1:294-299

15. De Werra I, Jaccard C, Corradin SB, et al (1997) Cytokines, nitrite/nitrate, soluble tumor necrosis factor receptors, and procalcitonin concentrations: Comparisons in patients with septic shock, cardiogenic shock, and bacterial pneumonia. Crit Care Med 25:607-613

16. Rau B, Steinbach G, Gansauge F, Mayer JM, Grünert A, Beger HG (1997) The potential role of procalci-tonin and interleukin- 8 in the prediction of infected necrosis in acute pancreatitis. Gut $41: 832-840$

17. Brunkhorst FM, Forycki ZF, Wagner J (1995) Frühe Identifikation der biliären akuten Pankreatitis durch Procalcitonin-Immunreaktivität - vorläufige Ergebnisse (Early identification of acute biliary pancreatitis with procalcitonin immunoreactivity - preliminary results). Chir Gastroenterol 11:S47 (Abst)

18. Gerard Y, Hober D, Petitjean S, et al (1995) High serum procalcitonin level in a 4-year-old liver transplant recipient with a disseminated candidiasis. Infection 23:310-311

19. Staehler M, Hammer C, Meiser B, Reichart B (1997) Procalcitonin: a new marker for differential diagnosis of acute rejection and bacterial infection in heart transplantation. Transplant Proc 29:584-585

20. Oberhoffer M, Bögel D, Meier-Hellmann A, Vogelsang H, Reinhart K (1996) Procalcitonin vs immunological markers in infection/inflammation. Br J Anaesth 76: A352 (Abst)

21. Oberhoffer M, Bitterlich A, Hentschel T, Meier-Hellmann A, Vogelsang H, Reinhart K (1996) Procalcitonin (ProCt) correlates better with the ACCP/SCCM consensus conference definitions than other specific markers of the inflammatory response. Clin Intensive Care 7:46 (Abst)

22. Al-Nawas B, Krammer I, Shah PM (1996) Procalcitonin in the diagnosis of severe infections. Eur J Med Res 1:331-333

23. Reith HB, Mittelkötter U, Kamen S, Beier W, Dohle J, Kozuschek W (1998) Langenb Arch Chir (in press)

24. Gerard Y, Hober D, Assicot M, et al (1997) Procalcitonin as a marker of bacterial sepsis in patients infected with HIV 1. J Infect 35:41-46

25. Smith MD, Suputtamongkol Y, Chaowagul W, et al (1995) Elevated serum procalcitonin levels in patients with melioidosis. Clin Infect Dis 20:641-645

26. Oberhoffer M, Bögel D, Meier-Hellmann A, Vogelsang H, Reinhart K (1996) Procalcitonin is higher in non-survivors during course of sepsis, severe sepsis, and septic shock. Intensive Care Med 22: A245 (Abst)

27. Smith RP, Lipworth BJ (1995) C-reactive protein in simple community acquired pneumonia. Chest 107:1028-1031

28. Erikson S, Grantström L, Olander BJ, Wretlind B (1995) Sensitivity of interleukin-6 and C-reactive protein concentrations in the diagnosis of acute appendicitis. Eur J Surg 161:41-45

29. Chwals WJ, Fernandez ME, Jamie AC, Charles BJ, Rushing JT (1994) Detection of postoperative sepsis in infants with the use of metabolic stress monitoring. Arch Surg 129:437-442

30. Shaw AC (1991) Serum C-reactive protein and neopterin concentrations in patients with viral or bacterial infection. J Clin Pathol 44:596-599

31. Monneret G, Labaune JM, Isaac C, Bienvenu F, Putet G, Bienvenu J (1997) Procalcitonin and C-reactive protein levels in neonatal infections. Acta Paediatr 86:209-212

32. Leser H-G, Gross V, Scheibenbogen C, et al (1991) Elevation of serum interleukin-6 concentration precedes acute phase response and reflects severity in acute pancreatitis. Gastroenterology $101: 782-785$

33. Kragsberbjer P, Holmberg H, Vikefors T (1995) Serum concentrations of interleukin-6, tumor necrosis factor-alpha, and C-reactive protein in patients undergoing major operations. Eur J Surg $161: 17-22$

34. Dandona P, Nix D, Wilson MF, et al (1994) Procalcitonin increase after endotoxin injection in normal subjects. J Clin Endocrinol Metab 79:1605-1608

35. Brunkhorst FM, Forycki ZF, Wagner J (1997) Release and kinetics of procalcitonin (PCT) after gram-negative bacterial injection in a healthy subject. Shock 7:124 (Abst)

36. Brunkhorst FM, Forycki ZF, Wagner J (1996) Identification of immunactivation of infectious origin by procalcitonin-immunreactivity in different body fluids. Clin Intensive Care 7:41 (Abst) 
37. Gramm H-J, Dollinger P, Beier W (1995) Procalcitonin-A new marker of host inflammatory response. Longitudinal studies in patients with sepsis and peritonitis. Chir Gastroenterol 11 (Suppl 2):51-54

38. Gramm H-J, Zimmermann J, Quedra N, Wegscheider K (1997) The procalcitonin (PROCT) response in severe sepsis is closely correlated to cytokine kinetics. Shock 7 (suppl 1): A489 (Abst)

39. Marnitz R, Gramm H-J, Zimmermann J (1997) Elaboration of mediators of inflammatory response after major surgery. Shock 7:124 (Abst)

40. Meisner M, Tschaikowsy K, Schmidt J, Schüttler J (1996) Procalcitonin (PCT) - Indications for a new diagnostic parameter of severe bacterial infection and sepsis in transplantation, immunosuppression, and cardiac assist devices. Cardiovasc Eng 1:67-76

41. Pilz G, Kreuzer E, Appel R, Werdan K (1997) Procalcitonin (PCT) serum levels in the early postoperative period of cardiac surgical patients at high risk for sepsis. Shock 7 (suppl 1) :A491 (Abst)

42. Bertagna XY, Nicholson WE, Pettengill OS, Sorensen GD, Mount CD, Orth DN (1978) Ectopic production of high molecular weight calcitonin and corticotropin by human small cell carcinoma cells in tissue culture: evidence for separate precursors. J Clin Endocrinol Metab 47: 1390-1393

43. Raue F, Blind E, Grauer A (1992) PDN-21 (katacalcin) and chromogranin A: tumor markers for medullary thyroid carcinoma. Henry Ford Hosp Med J 40:296-298 